\title{
Enteric methane output from selected herds of beef cattle raised under extensive arid rangelands
}

\author{
L. Mapfumo ${ }^{1 *}$, S. M. Grobler' ${ }^{2}$ J. F. Mupangwa'1', M. M. Scholtz²,3 and V. Muchenje
}

\begin{abstract}
Extensively raised beef cattle contribute to the highest levels of enteric methane $\left(\mathrm{CH}_{4}\right)$ gas emissions among all livestock. Expensive techniques and logistics hinder monitoring of such gas. Therefore, the objective of this study was to use an inexpensive laser methane detector $(\mathrm{LMD})$ apparatus to determine the enteric $\mathrm{CH}_{4}$ levels from a herd of beef cows raised on semi-arid rangelands. A total of 24 cows were selected from Boran and Nguni cows $(n=12$ per breed) from two different farms. The parities of the cows were as follows: parity $1(n=6)$, parity $2(n=6)$, parity $3(n=6)$ and parity $4(n=6)$. An observer used a hand-held LMD to measure enteric $\mathrm{CH}_{4}$ emissions plumes during the late afternoon hours when the animals were resting (either standing or lying down). Point measurements (expressed in $\mathrm{ppm} / \mathrm{m}$ ) were taken for six consecutive days and repeated once after every three months. The ratio of $\mathrm{CH}_{4}$ output per kilogramme DMI was not different in within-breed and between-breed in both seasons. Generally, the dry season recorded the highest $\mathrm{CH}_{4}$ output per kilogramme of live weight of cow. For example, Boran cows in parity 2 produced the highest output of $1.0 \pm 0.04 \mathrm{~g} \mathrm{CH}_{4}$ per kilogramme live weight of cow while Nguni cows in parities 1, 2 and 4 each produced $0.9 \pm 0.04 \mathrm{~g} \mathrm{CH}_{4}$ per kilogramme live weight of cow in the dry season. All the animals maintained optimal body condition scores in both seasons (ranging between the lowest of $3.2 \pm 0.01$ and the highest of $3.4 \pm 0.01$ ). Based on the results of the study, it is concluded that cows from both herds produced higher $\mathrm{CH}_{4}$ per kilogramme live weight of cow in the dry season while maintaining optimal body condition scores in both seasons.
\end{abstract}

Keywords: Extensive grazing system, Greenhouse gases, Laser methane detector

\section{Introduction}

Currently, available information on enteric methane $\left(\mathrm{CH}_{4}\right)$ output from extensively raised beef cattle under extensive arid and semi-arid African environments varies from limited to non-existent. The limitations emanate from either complications in logistics or expensive techniques. To develop expert recommendations that will inform policy makers, there is a need to generate such knowledge to fill the gaps. Most of the sub-Saharan African countries have to lower their carbon footprint, because of lower digestion efficiency of forages from poor quality rangelands, when expressed at an individual animal level (Avetisyan et al. 2011). Generally, ruminants

\footnotetext{
* Correspondence: Imapfumo@ufh.ac.za

'Department of Livestock and Pasture Science, University of Fort Hare, P. Bag X1314, Alice 5700, South Africa

Full list of author information is available at the end of the article
}

reared extensively have a low footprint per unit area than those reared under intensively grain-fed systems, although on the contrary they produce higher footprint when expressed on an emissions $/ \mathrm{kg}$ product (emissions intensity) basis (Garnett 2010; Scholtz et al. 2013). Currently, South Africa is one of the highest producers of greenhouse gasses (GHG) $\left(\mathrm{CH}_{4}\right.$ included) in subSaharan Africa (Chevallier 2008). Du Toit et al. (2013) reported that enteric methane emissions factors for South Africa were 79 and $62.4 \mathrm{~kg} / \mathrm{head} /$ year for commercial and communal beef cattle, respectively; compared with an overall average of $31 \mathrm{~kg} / \mathrm{head} /$ year for Africa based on IPCC default values. As a result, climate smart activists are calling for practical methods, which will enhance in vivo monitoring, selection of low $\mathrm{CH}_{4}$ producing animals and mitigating for low carbon footprint per unit area or kilogramme of animal product. 
Approximately two thirds of the total land area in South Africa receives an average annual rainfall of less than $500 \mathrm{~mm}$, and a further $21 \%$ is arid receiving less than $200 \mathrm{~mm}$ of rainfall per year (Basson 2011). It then means most of the South African farms are located in arid and semi-arid drylands. Beef cattle are capable of utilising fibrous forage material from such marginal environments and turn it into edible animal-derived products that can contribute positively to the food-value chain system (Gerber et al. 2015). There are various beef cattle breeds, which have proved to cope and survive in such extensive challenging conditions over a long period. In South Africa, such breeds include those of Sanga (Bos taurus africanus) and Zebu (Bos indicus) origin. Nguni cattle are of Sanga origin, and research has shown that they can cope and adapt to extensive environments where nutrition is limiting. However, given that extensively reared cattle must conform to acceptable ranges of carbon footprint in the future, there is a need to develop an inexpensive method to determine how much greenhouse gas (GHG) is emitted by such breeds.

There is a need to invest in reasonably inexpensive methods, which quantifies emission levels of GHG for use in national inventories (Chagunda et al. 2013; Du Toit et al. 2013; Hammond et al. 2016). Traditionally, enteric $\mathrm{CH}_{4}$ concentration levels have been measured using several methods: micro-meteorology method, IPCC Tier systems, $\mathrm{SF}_{6}$ method, respiration chambers and prediction models (Storm et al. 2012; Hammond et al. 2016). Each method has its advantages and inadequacies; therefore, there is a need to make careful evaluation before application (Storm et al. 2012; Troy et al. 2016). Generally, there are non-contact and non-invasive techniques, which are feasible to use in extensive rangelands. Use of a laser methane detector (LMD) promises to be feasible among such techniques, as it has been reported to make biological sense, to be a reasonable method which advances $\mathrm{CH}_{4}$ detection and contributes towards the effectiveness of $\mathrm{m} \mathrm{CH}_{4}$ mitigation strategies (Chagunda et al. 2009; Chagunda et al. 2013; Chagunda 2013; Grobler et al. 2014). Therefore, the objective of this study was to determine the enteric $\mathrm{CH}_{4}$ levels from selected herds of beef cows raised on semi-arid rangelands, using the LMD method.

\section{Study area}

The first herd (herd 1) was composed of Boran cows, sourced from the Edendale farm which is in Fort Beaufort at $32.9^{\circ} \mathrm{S}$ latitude and $26.6^{\circ} \mathrm{E}$ longitude in the Amathole District Municipality of the Eastern Cape Province of South Africa. The altitude is $429 \mathrm{~m}$ above sea level, average annual temperature of $18.3{ }^{\circ} \mathrm{C}$, with an annual rainfall average of $498 \mathrm{~mm}$ on a normal rainy season. The vegetation quality is classified as the Bisho
Thornveld of the Eastern Cape (Mucina and Rutherford 2011). The grass species from the veld are composed of Sporobolus fimbriatus, Digitaria eriantha, Setaria neglecta, Cymbopogon plurinodis, Panicum maximum, Eragrostis obtusa, Aristida congesta and Cymbopogon excavatus. Woody species are composed of Rhus longispina, Acacia karroo, Moytinus capitata, Ehretia rigida and Justica oak. This farm is about $30 \mathrm{~km}$ away from Honeydale farm where the Nguni cows were located.

The second herd (herd 2) had Nguni cows from Honeydale Research farm located at University Fort Hare in Alice. The farm is located $120 \mathrm{~km}$ from the coastline of the Eastern Cape Province of South Africa. It has an elevation ranging from 450 to $600 \mathrm{~m}$ above sea level, longitude of $26.9^{\circ} \mathrm{E}$ and latitude $32.8^{\circ} \mathrm{S}$; in a good rainy season, it receives a total annual rainfall ranging from 500 to $550 \mathrm{~mm}$, between November and March (Acocks 1988). The vegetation type for the farm is classified as the Bisho Thornveld of the Eastern Cape in South Africa (Mucina and Rutherford 2011). The veld is mainly composed of invasive tree species such Acacia karroo while the other trees include Maytens heterophylla, Scutia indica, Ehretia rigida, Rhus longispina, Olea africana, Grewia accidentials, Ziziphus mucronata and Cussonia spicata. Themeda triandra is the dominant grass species, and Sporobolus fimbriatus, Cymbopogon excavatus, Eragrostis curvula, Aristida congesta, Eragrostis capensis, Panicum maximum and Digitaria eriantha are the other grasses on the veld. The veld quality is classified as a sweet-veld type, with a fairly good nutritive value (Acocks 1988; van Oudtshoorn 2012). Deep alluvial derived soil types are found in arable lands while shallow portions of the non-arable land are occupied by fine sand and silt (below 45-cm depth).

\section{Materials and methods}

All protocols and procedures followed in this study were according to the ethical principles for use of animals in experiments established by the Committee of Ethics on Animal Use. Permission to use animals in this trial was granted by the University of Fort Hare Research Ethics Committee.

A total of 24 cows (12 from each breed) were randomly selected for the study. The animals were identified according to their parities as follows: parity $1(n=6)$, parity $2(n=6)$, parity $3(n=6)$ and parity $4(n=6)$. Each individual cow was identified by use of a plastic ear tag with its corresponding number. The cows grazed on a rangeland divided into paddocks and were moved from one paddock to another once after every 21 days. Because of nonuniform size of paddocks, stocking density from the two herds was $7 \mathrm{ha} / \mathrm{LSU}$. A large stock unit is equivalent to an animal with a weight of $450 \mathrm{~kg}$, gaining $500 \mathrm{~g} /$ day and 
having energy requirements of $75 \mathrm{MJ} /$ day (Meissner et al. 1983). All cows had unlimited access to water from the water-troughs in each paddock. Within the grazing period in one paddock, the animals were allowed an adaptation period of 14 days followed by recordings of $\mathrm{CH}_{4}$ production for six consecutive days in a month and replicated twice in three months.

An observer used a hand-held LMD (Crowcon, Tokyo Gas Engineering Co Ltd 2006) to measure the enteric $\mathrm{CH}_{4}$ production in the late afternoon hours when the animals were resting (either standing or lying down). Point measurements (expressed in $\mathrm{ppm} / \mathrm{m}$ ), were taken continuously for four minutes by $60 \mathrm{~s}$ intervals at a distance of $3 \mathrm{~m}$ away from each animal following the method by Jones et al. (2011). Due to the cyclic nature of the data (respiratory tidal cycle), a point measurement over each exhalation-inhalation cycle was taken. The peaks of each cycle determined the enteric methane output of the individual cows. Before commencing measurements for each day, the LMD was off-set to adjust it to the ambient $\mathrm{CH}_{4}$. Off-setting the LMD is done to account for the $\mathrm{CH}_{4}$ in the environment before the machine records the gas concentrations from the point source (Chagunda and Yan 2011). Gas column density for $\mathrm{CH}_{4}$ were determined by pointing the (visble $\mathrm{HeNe}$ laser) collimated laser beam on the cow's nostril to estimate the gas concentration $3 \mathrm{~m}$ away from each cow (Chagunda et al. 2009; Jones et al. 2011; McGinn et al. 2011). The 3-m distance was chosen such that the observer does not disturb each cow from its state of rest and was subsequently used to convert the $\mathrm{ppm} / \mathrm{m}$ into $\mathrm{ppm}$ (Chagunda et al. 2009; Chagunda 2013). These measurements were done in both wet and dry months of the year. The wet months were from November to early May while dry months were from mid-May to October. A pocket weather instrument (Kestrel 4000) was used to determine the following environmental conditions: ambient temperature, wind speed and relative humidity for the study site. Summary of the weather conditions for the two sites used in the study is given in Table 1.

All cows from both herds were weighed once a month. Before weighing, all cows were assessed for body condition on a scale of 1 to 5 ( 1 being emaciated and 5

Table 1 The weather conditions during the trial period at the two farms occupied by the Boran and Nguni cows

\begin{tabular}{llllll}
\hline & \multicolumn{2}{l}{ Herd 1 } & & Herd 2 \\
\cline { 2 - 3 } Attributes & Season & & & \\
\cline { 2 - 3 } & Wet & Dry & & Wet & Dry \\
\hline Ambient temperature $\left({ }^{\circ} \mathrm{C}\right)$ & 27.3 & 31.8 & & 28.1 & 31.2 \\
Relative humidity $(\%)$ & 56.5 & 53.4 & & 57.1 & 58.2 \\
Wind speed $(\mathrm{m} / \mathrm{s})$ & 0.95 & 1.1 & & 1.2 & 0.91 \\
Rainfall $(\mathrm{mm})$ & 121 & 78 & & 187 & 89 \\
\hline
\end{tabular}

classified as obese) according to Enicias and Lardy (2002). The body condition scores were done by visual appraisal and palpation of the spinal process of each individual cow. Routine animal management processes such as dipping, vaccination and drenching were also followed to maintain the health of the cows.

Pasture samples were collected once every three months to determine the plant biomass of the paddocks during the course of the experiment. Each paddock was divided into transects measuring $100 \mathrm{~m}$ long and $25 \mathrm{~m}$ apart (Goqwana and Trollope 2005). Grass biomass was determined by placing a $1-\mathrm{m}^{2}$ quadrat along each transect and collecting all foraging material within it. All the collected forage was transferred into paper bags and oven dried at $65{ }^{\circ} \mathrm{C}$ for $48 \mathrm{~h}$ to obtain the dry matter of the material. The resultant dried sample was then weighed using a digital scale. The weight of forage biomass expressed in $\mathrm{g} / 1 \mathrm{~m}^{2}$ was then converted to kilogrammes per hectare basis by multiplying the obtained mass by a factor of 10 . The forage biomass for Honeydale farm was $2047 \mathrm{~kg} / \mathrm{ha}$ in the wet period and had an average of $1039 \mathrm{~kg} / \mathrm{ha}$ in the dry period. Edendale farm had a forage biomass of $1939 \mathrm{~kg} / \mathrm{ha}$ in the wet period and $1023 \mathrm{~kg} / \mathrm{ha}$ in the dry period. The chemical composition of the pasture samples in the different months of the year are found in our previous work (Mapfumo et al. 2017).

The point measurements from each cow under investigation were used to estimate the amount of $\mathrm{CH}_{4}$ produced per day. The amount of methane produced was expressed as a proportion of the tidal volume (Tenney 1982). Calculations derived from the tidal volume were then converted into grammes per day using the density for $\mathrm{CH}_{4}$ following the formulae developed by Chagunda et al. (2009). The following formulae was used:

$$
\mathrm{M}_{\mathrm{DG}}=0.000576 \times \mathrm{MTV} \times \mathrm{TVr}
$$

where $\mathrm{M}_{\mathrm{DG}}$ is the daily enteric $\mathrm{CH}_{4}$ expressed in grams after including the specific density conversion factor, $\mathrm{M}_{\mathrm{TV}}$ is the methane from breath point measurements in millilitres during ruminating and $\mathrm{TV}_{\mathrm{r}}$ represents the tidal volume of air when the animals were resting (either standing or lying down).

Dry matter intake (DMI) was derived from the values developed by Meissner et al. (1983). Data on DMI was then used to make calculations of the subsequent $\mathrm{CH}_{4}$ output per kilogramme DMI and $\mathrm{CH}_{4}$ per kilogramme of live weight for each individual cow from both herds.

All quantitative data of the response variables from this study were analysed using the Statistical Analysis System (SAS) version 9.3. Body condition score values were square-root transformed to confer them to follow the normal distribution. The body condition scores were 
then back-transformed as a way of presenting normal standard interpretable results after analysis. A nested design was run to test the effects of parity and season including their (fixed factors) interaction on estimated enteric methane production, $\mathrm{CH}_{4}$ output per kilogramme DMI, $\mathrm{CH}_{4}$ per kilogramme of live weight and body condition scores of the Boran and Nguni cows using the PROC MIXED of SAS version 9.3. Means for estimated enteric methane production, $\mathrm{CH}_{4}$ output per kilogramme DMI, $\mathrm{CH}_{4}$ per kilogramme of live weight and body condition scores were separated using the Fishers' least significant differences (LSD) method and considered significant at $P<0.05$.

A second nested design was done using the MIXED procedure of SAS version 9.3 as a repeated measure to determine the effects of parity on the $\mathrm{CH}_{4}$ levels during the different days of sampling. Parity was included in the model as a fixed factor while the individual cow weight was considered as a random variable. A first order autoregressive correlation (AR [1]) was fitted into the model to account for the connection of $\mathrm{CH}_{4}$ production level between successive days. The Fishers' least significant differences (LSD) method was the post-hoc test used to separate means for methane production and considered significant at $P<0.05$.

\section{Results}

Detailed daily average output for the $\mathrm{CH}_{4}$ for both breeds over the six-day sampling period is in Figure 1. Both breeds had fluctuating $\mathrm{CH}_{4}$ throughout the days of sampling. All the cows maintained a similar range of daily enteric $\mathrm{CH}_{4}$ output throughout the six-day sampling period for both seasons. Nguni cows in parity 3 $(263.8 \pm 31.25 \mathrm{~g} /$ day $)$ and Boran cows in parity 4 (301.4 $\pm 25.51 \mathrm{~g} /$ day $)$ had the lowest $(P<0.05)$ daily $\mathrm{CH}_{4}$ at day 5. Fluctuations in $\mathrm{CH}_{4}$ production on a daily basis are changes dependent on the quality and quantity of the diet from the previous day.

Table 2 shows the results for $\mathrm{CH}_{4}$ output per kilogramme DMI and $\mathrm{CH}_{4}$ per kilogramme of live weight. There were however no differences $(P>0.05)$ for $\mathrm{CH}_{4}$ output per kilogramme DMI from all the cows withinbreed in both seasons. The $\mathrm{CH}_{4}$ per kilogramme of live weight were all within the same range from both breeds, although there were within-breed differences $(P<0.05)$ in both seasons. Boran cows in parities 2 and 3 had a 0 . 1-g difference in $\mathrm{CH}_{4}$ output per kilogramme of live weight of cow from the dry to wet season. Boran cows in parity 2 had $1.0 \pm 0.04 \mathrm{~g}$ in the dry season and $0.9 \pm 0$. $04 \mathrm{~g}$ of $\mathrm{CH}_{4}$ output per kilogramme of live weight of cow in the wet season, those in parity 3 had $0.9 \pm 0.04$ and $0.8 \pm 0.04 \mathrm{~g}$ of $\mathrm{CH}_{4}$ output per kilogramme of live weight of cow for the dry and wet seasons, respectively. On the contrary, only Nguni cows in parity 2 maintained the same $(P>0.05) 0.9 \pm 0.04 \mathrm{~g}$ of $\mathrm{CH}_{4}$ output per kilogramme of live weight of cow in both seasons.

Results of the back-transformed body condition scores of the cows, in different parities from Boran and Nguni breeds are in Figure 2. All cows from both breeds had similar $(P>0.05)$ body condition scores in the wet season (Figure 2). Boran cows in parities 2 and 3 had the lowest $(P<0.05)$ condition scores $(3.2 \pm 0.01)$ among the cows in the study in the dry season. All the animals maintained optimal body condition scores both in dry and wet seasons (ranging from $3.2 \pm 0.01$ to $3.4 \pm 0.01$ ). Such a trend shows that both breeds were using mechanisms to adjust and cope within their surrounding environments. Nguni cows (least being $3.3 \pm 0.01$ ), however, maintained optimally higher body condition scores than those of the Boran cows (least being $3.2 \pm 0.01$ ) in the dry season.

\section{Discussion}

The values for the $\mathrm{CH}_{4}$ output found in this study are within the range of reports from other studies. Chagunda et al. (2009) obtained $\mathrm{LMD} \mathrm{CH}_{4}$ estimates of $357 \mathrm{~g} /$ day for dairy cattle. However, output from the current study is higher than that reported by Du Toit et al. (2013) using the IPCC Tier 2 system for South African commercial beef cattle. From their calculation, they estimated that on average, a beef cow with a $475-\mathrm{kg}$ weight produces $92.6 \mathrm{~kg} \mathrm{CH}_{4}$ per head in a year (averaging to approximately $254 \mathrm{~g} /$ day/cow). High output could have emanated from the extreme dry conditions, which were prevailing in southern Africa during the 2015/16 rain season when this study was undertaken. This is evident from reports indicating that moisture availability has a direct positive correlation on forage output or plant life under rain-fed southern African rangelands (Mpandeli et al. 2015; Rasch et al. 2017; Senyolo et al. 2017). Therefore, dry conditions cause low quality forage biomass, which likely result in higher energy losses by animals when degraded in the rumen. Ruminants produce methane through inefficiencies that are associated with energy loss from methanogenis (Johnson and Johnson 1995; MacDonald et al. 2010; Cottle et al. 2011). Microbata called methanogenic Archaea play a central role in digestion of feed (Hill et al. 2016). Therefore, the dry conditions could have contributed to the higher $\mathrm{CH}_{4}$ output per live weight of cow from the highly fibrous forage, which is difficult to degrade.

The fluctuation in $\mathrm{CH}_{4}$ output from this experiment was within a narrow range, further showing that cows from both breeds had similar outputs on a daily basis. Maintenance of daily $\mathrm{CH}_{4}$ production within a defined range depends on the diet consumed by the host animal when grazing in the veld. Based on the chemical 

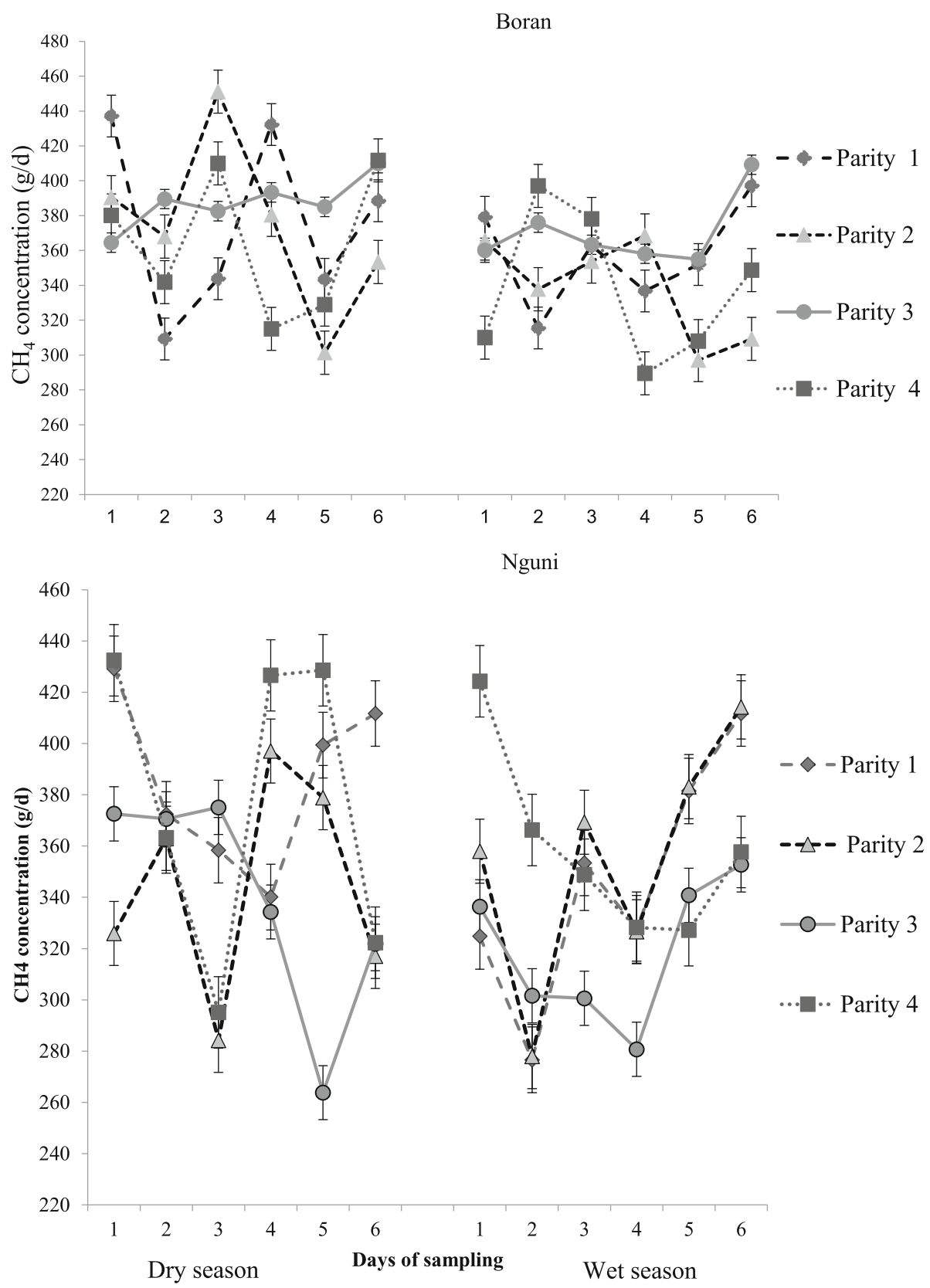

Figure 1 Seasonal changes in daily (mean \pm s.e) $\mathrm{CH}_{4}$ concentration from the cows in different parities

composition in our earlier work, the natural pastures from both sites had similar total digestible nutrients and energy content (Mapfumo et al. 2017). Therefore, the enteric $\mathrm{CH}_{4}$ output by the cows could have been influenced by the amount of feed consumed, digesta retention time and out flow rates and ultimately determined by inter-and intra-animal variation (Hammond et al. 2014; Vendl et al. 2016). Such a range and fluctuations in $\mathrm{CH}_{4}$ production by the cows from both breeds could have come from the mode of foraging habits and availability of feed to the animals. Reports mention that extensively raised animals search for feed within the stretch of their confined areas, and the heterogeneity in forage quality therefore defines an uneven trend for forage availability on a daily basis (Spinka 2006; Estevez et al. 2007).

The stocking rate of the two separate farms was maintained the same, in spite of the changes in seasons. Animal production attributes such as milk production, body condition score and body weight are negatively 
Table 2 Ratio of methane output per kilogramme DMl and methane output per kilogramme of live weight from the two herds

\begin{tabular}{|c|c|c|c|c|}
\hline Season & Breed & Parity & $\mathrm{CH}_{4}$ output/DMI $(\mathrm{g} / \mathrm{kg})$ & $\mathrm{CH}_{4}$ output $/ \mathrm{LW}(\mathrm{g} / \mathrm{kg})$ \\
\hline \multirow[t]{8}{*}{ Dry } & \multirow[t]{4}{*}{ Boran } & 1 & $30.3^{\mathrm{a}} \pm 1.15$ & $0.8^{\complement} \pm 0.04$ \\
\hline & & 2 & $31.9^{a} \pm 1.36$ & $1.0^{a} \pm 0.04$ \\
\hline & & 3 & $30.5^{\mathrm{a}} \pm 1.20$ & $0.9^{b} \pm 0.04$ \\
\hline & & 4 & $28.8^{\mathrm{a}} \pm 1.32$ & $0.8^{\complement} \pm 0.04$ \\
\hline & \multirow[t]{4}{*}{ Nguni } & 1 & $32.2^{\mathrm{a}} \pm 1.34$ & $0.9^{b} \pm 0.04$ \\
\hline & & 2 & $31.9^{\mathrm{a}} \pm 1.34$ & $0.9^{b} \pm 0.04$ \\
\hline & & 3 & $30.4^{a} \pm 1.62$ & $0.8^{c} \pm 0.05$ \\
\hline & & 4 & $32.8^{\mathrm{a}} \pm 1.32$ & $0.9^{b} \pm 0.04$ \\
\hline \multirow[t]{8}{*}{ Wet } & \multirow[t]{4}{*}{ Boran } & 1 & $26.6^{\mathrm{a}} \pm 1.15$ & $0.8^{\complement} \pm 0.04$ \\
\hline & & 2 & $29.5^{\mathrm{a}} \pm 1.32$ & $0.9^{b} \pm 0.04$ \\
\hline & & 3 & $30.4^{\mathrm{a}} \pm 1.17$ & $0.8^{c} \pm 0.04$ \\
\hline & & 4 & $27.1^{\mathrm{a}} \pm 1.32$ & $0.8^{c} \pm 0.04$ \\
\hline & \multirow[t]{4}{*}{ Nguni } & 1 & $29.2^{\mathrm{a}} \pm 1.34$ & $0.8^{c} \pm 0.04$ \\
\hline & & 2 & $31.0^{\mathrm{a}} \pm 1.32$ & $0.9^{b} \pm 0.04$ \\
\hline & & 3 & $26.5^{\mathrm{a}} \pm 1.62$ & $0.7^{d} \pm 0.05$ \\
\hline & & 4 & $30.1^{a} \pm 1.32$ & $0.8^{\complement} \pm 0.04$ \\
\hline
\end{tabular}

a, b, c, d LS means with a different superscript in the same column per category are significantly different at $P<0.05$, LS Least square, $L W$ Live-weight, DMI Dry Matter Intake correlated with the increase in stocking rate (McCarthy et al. 2014). Research indicated that an increase in stocking rate results in increased grazing intensity, which will subsequently result in lower daily herbage allowance (McCarthy et al. 2011). Changes in seasons from wet to dry meant that available forage material is fibrous and is not palatable, hence lowering DMI. Nguni cattle minimise energy loss in the dry season through deliberate voluntary anorexia and feeding during the cooler hours of the day (Scholtz 2011). The cattle are also bulky grazers unlike other breeds, which are selective grazers. This causes Nguni cattle to, minimally, lose condition, during periods when feed resources are scarce. Boran cattle have survived in challenging African terrain for a long period to evolve and have attributes that allow them to manage situations where forage is in short supply. The animals store fat deposits during the periods when feed resources are abundant and later on use them when the forage availability is low (Berman 2011). Such mechanisms could have contributed to maintenance of body condition scores at optimal levels in this study.

\section{Conclusion}

Both the Nguni and Boran breed showed no differences in $\mathrm{CH}_{4}$ output per kilogramme DMI while

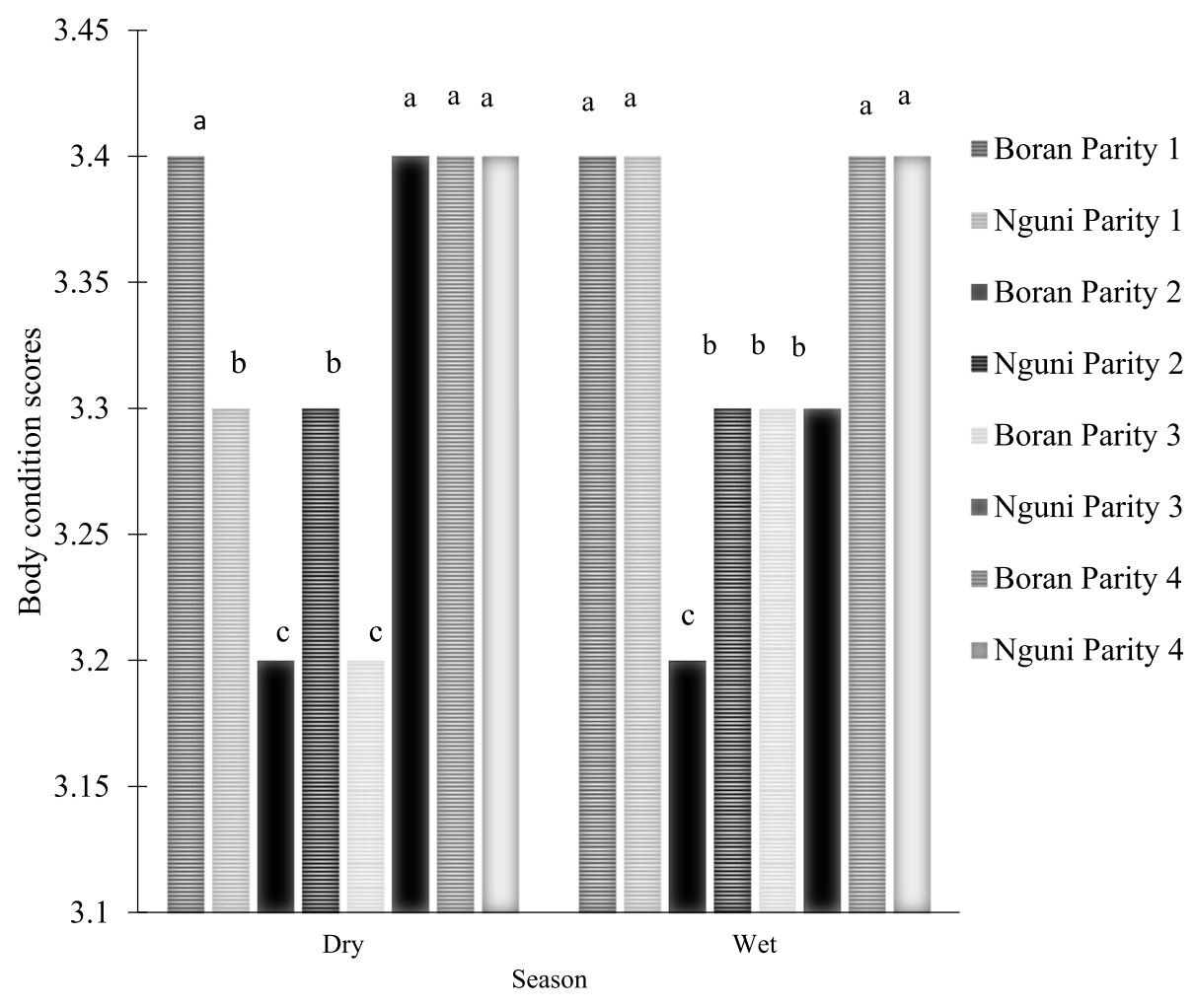

Figure 2 Seasonal changes in average body condition scores of Boran (herd 1) and Nguni (herd 2) cows in different parities 
within-breed differences for $\mathrm{CH}_{4}$ output per kilogramme of cows' live weight were observed in both seasons. Based on the results obtained in this study, both the Boran and Nguni breed had similar direct methane output irrespective of occupying different rangelands. This could be attributed from the similar non-selective foraging behaviour and mechanisms, which they use to adapt to their environment. The study also showed that an LMD machine can be used to produce reasonable values for $\mathrm{CH}_{4}$ output for extensively-raised beef cattle.

\section{Abbreviations \\ CH4: Methane; DMI: Dry matter intake; GHG: Greenhouse gas; LMD: Laser methane detector; LSU: Large stock unit; SAS: Statistical Analysis System}

\section{Acknowledgements}

We greatly appreciate Stephen Johnson who offered us the opportunity to work with his Boran cows. We also would like to acknowledge all stockmen from Honeydale farm for helping availing the Nguni cows.

\section{Funding}

This research was sponsored by Adam Fleming as the Nguni Cattle project (Project P329) and the National Research Foundation RTF projects (IUD numbers RTF150329116339 and RTF150522118247). This work was presented at the South African Society for Animal Science, Boardwalk, Port Elizabeth (18 to 21 September 2017), and therefore, the authors would like to thank the Govan Mbeki Research and Development Centre for funding the leading author attend the conference.

\section{Availability of data and materials}

Please contact the author for data requests.

\section{Authors' contributions}

LM conceptualised the idea, carried out the study and wrote the manuscript; VM helped in conceptualising the idea behind the study, sourced funding and compilation and editing of the manuscript; JFM helped in conceptualising the idea and editing of the manuscript; MMS helped in laying out the experimental design and editing of the manuscript; SMG helped in the use of the LMD in methane measurements. All authors read and approved the final manuscript.

\section{Competing interests}

The authors of this article declare no conflict of interest with any organisation or entity with any financial or non-financial support to the study. The grant holder also acknowledges that opinions, findings and conclusions or recommendations expressed in this publication are of the authors and that the sponsors hold no liability whatsoever in this regard.

\section{Publisher's Note}

Springer Nature remains neutral with regard to jurisdictional claims in published maps and institutional affiliations.

\section{Author details}

'Department of Livestock and Pasture Science, University of Fort Hare, P. Bag X1314, Alice 5700, South Africa. ${ }^{2}$ ARC-Animal Production Institute, P. Bag X2, Irene 0062, South Africa. ${ }^{3}$ Department of Grasslands and Wildlife Sciences, University of the Free State, P.O. Box 339, Bloemfontein 9300, South Africa.

Received: 9 November 2017 Accepted: 9 April 2018

Published online: 18 May 2018

\section{References}

Acocks, J.P.H., 1988. Veld types of South Africa. Third ed. Memoirs of botanical survey of South Africa. Government Printer, Pretoria, pp. 1-146.

Avetisyan, M., A. Golub, T. Hertel, S. Rose, and B. Henderson. 2011. Why a global carbon policy could have a dramatic impact on the pattern of the worldwide livestock production. Applied Economics Perspective Policy 33 584-605. https://doi.org/10.1093/aepp/ppr026.

Basson, M.S. 2011. Water development in South Africa, UN-Water International Conference. Water in the green economy in practice: Towards Rio+20, 3-5. Zaragoza. http://www.un.org/waterforlifedecade/green_economy_2011/pdf/ session_1_economic instruments south_africa.pdf.

Berman, A. 2011. Invited review: Are adaptations present to support dairy cattle productivity in warm climates? Journal of Dairy Science 94: 2417-2158. https://doi.org/10.3168/jds.2010-3962.

Chagunda, M.G.G. 2013. Opportunities and challenges in the use of the Laser Methane Detector to monitor enteric methane emissions from ruminants. Animal 7: 394-400. https://doi.org/10.1017/S1751731113000724.

Chagunda, M.G.G., D. Ross, and D.J. Roberts. 2009. On the use of a laser methane detector in dairy cows. Computers Electronics in Agriculture 68: 157-160 doi. org/10.1016/j.compag.2009.05.008.

Chagunda, M.G.G., D. Ross, J. Rooke, T. Yan, J.-L. Douglas, L. Poret, N.R. McEwan, P. Teeranvattanakul, and D.J. Roberts. 2013. Measurement of enteric methane from ruminants using a hand-held laser detector. Acta Agriculture Scandinavia Section A 63: 68-75.

Chagunda, M.G.G., and T. Yan. 2011. Do methane measurements from laser detector and indirect open-circuit respiration calorimetric chamber agree sufficiently closely? Animal Feed Science and Technology 165: 8-14. https:// doi.org/10.1016/.j.anifeedsci.2011.02.005.

Chevallier, R. 2008. Addressing mitigation of and adaptation to climate change in sub-Saharan Africa while meeting development goals. South African Yearbook of International Affairs. Accessed from https://www.saiia.org.za/images/ stories/research/garp/climate_change/saiia_yearbook_2008-9_mitigation_ climate_chevallier_pg171-190.pdf.

Cottle, D.J., J.V. Nolan, and S.G. Wiedemann. 2011. Ruminant enteric methane mitigation: A review. Animal Production Science 51: 491-514. https://doi.org/ 10.1071/AN10163.

Crowcon Detection Instruments. 2006. New hand held device detects methane up to 150 metres away. http://halmapr.com/news/crowcon/2006/11/16/newhand-held-device-detects-methane-up-to-150-metres-away/.

Du Toit, C.J.L., H.H. Meissner, and W.A. van Niekerk. 2013. Direct methane and nitrous oxide emissions of South African dairy and beef cattle. South African Journal of Animal Science 43: 320-339.

Enicias, A. M., Lardy, G., 2002. Body condition scoring: Managing your herd through body condition scoring. https://library.ndsu.edu/ir/bitstream/handle/ 10365/5343/as1026.pdf? sequence=1\&isAllowed $=y$.

Estevez, I., I. Anderson, and E. Nævdal. 2007. Group size, density and social dynamics in farm animals. Applied Animal Behaviour Science 103: 185-204 doi. org/10.1016/j.applanim.2006.05.025.

Garnett, T., 2010. Intensive versus extensive livestock systems and greenhouse gas emissions. FCRN briefing paper.

Gerber, P.J., A. Mottet, C.I. Opio, A. Falcucci, and F. Teillard. 2015. Environmental impacts of beef production: Review of challenges and perspectives for durability. Meat Science 109: 2-12 doi.org/10.1016/j.meatsci.2015.05.013.

Goqwana, W.M. Trollope, WS., 2005. Simplified technique for assessing the condition of the grass sward in the Cymbopogon-Themeda veld in Southern Free State and North Eastern Cape Province of South Africa, vol 5. Grassroots: Newsletter of the Grassland Society of Southern Africa.

Grobler, S.M. M.M. Scholtz, H. van Rooyen, M. Mpayipheli, and F.W.C. Neser. 2014 Methane production in different breeds, grazing different pastures or fed a total mixed ration, as measured by a laser methane detector. South African Journal of Animal Science 44: S12-S16.

Hammond, K.J., L.A. Crompton, A. Bannink, J. Dijkstra, D.R. Yáñez-Ruiz, P. O'Kiely, E. Kebreab, M.A. Eugène, Z. Yuh, K.J. Shingfieldi, A. Schwarm, A.N. Hristov, and C.K. Reynolds. 2016. Review of current in-vivo measurement techniques for quantifying enteric methane emission from ruminants. Animal Feed Science and Technology 219: 13-30 doi.org/10.1016/j. anifeedsci.2016.05.018.

Hammond, K.J., D. Pacheco, J.L. Burke, J.P. Koolard, S. Muetzel, and G.C. Waghorn. 2014. The effects of fresh forages and feed intake level on digesta kinetics and enteric methane emissions from sheep. Animal Feed Science and Technology 193: 32-43 doi.org/10.1016/j.anifeedsci.2014.04.005.

Hill, J., C. McSweeney, A.G. Wright, G. Bishop-Hurley, and K. Kalantar-zade. 2016. Measuring Methane Production from Ruminants. Trends in Biotechnology. 34(1), 26-35. http://dx.doi.org/10.1016/j.tibtech.2015.10.004.

Johnson, KA. and DE. Johnson. 1995. Methane emissions from cattle. Journal of Animal Science 73: 2483-2492. 
Jones, F.M., F.A. Phillips, T. Naylor, and N.B. Mercer. 2011. Methane emissions from grazing Angus beef cows selected for divergent residual feed intake. Animal Feed Science Technology 166-167: 302-307 doi.org/10. 1016/j.anifeedsci.2011.04.020.

MacDonald, P., R.A. Edwards, J.F.D. Greenhalgh, C.A. Morgan, L.A. Sinclair, and R.G. Wilkinson. 2010. Animal nutrition, 7th edition. London: Prentice Hall.

Mapfumo, L., V. Muchenje, J.F. Mupangwa, and M.M. Scholtz. 2017. Changes in biochemical proxy indicators for nutritional stress resilience from Boran and Nguni cows reared in dry arid rangeland. Tropical Animal Health and Production. https://doi.org/10.1007/s11250-017-1338-0.

McCarthy, B., L. Delaby, K.M. Pierce, F. Journot, and B. Horan. 2011. Meta-analysis of the impact of stocking rate on the productivity of pasture-based milk production systems. Animal 5: 784-794. https://doi.org/10.1017/ S1751731110002314.

McCarthy, J., B. McCarthy, B. Horan, K.M. Pierce, N. Galvin, A. Brennan, and L. Delaby. 2014. Effect of stocking rate and calving date on dry matter intake, milk production, body weight, and body condition score in spring-calving, grass-fed dairy cows. Journal of Dairy Science. 97: 1693-1706. https://doi.org/ 10.3168/jds.2013-7458.

McGinn, S.M., D. Turner, N. Tomkins, E. Charmley, G. Bishop-Hurley, and D. Chen. 2011. Methane emissions from grazing cattle using point-source dispersion. Journal of Environmental Quality 40: 22-27. https://doi.org/10.2134/jeq2010.0239.

Meissner, H.H., H.S. Hofmeyr, W.J.J. van Rensburg, and J.P. Pienaar. 1983. Classification of livestock for realistic prediction of substitution values in terms of biologically defined large stock unit. Pretoria, Republic of South Africa: Technical communication, Department of Agriculture.

Mpandeli, S., E. Nesamvuni and P. Maponya. 2015. Adapting to the Impacts of Drought by Smallholder Farmers in Sekhukhune District in Limpopo Province, South Africa. Journal of Agricultural Science; Vol. 7(2):115-124. http://dx.doi.org/10.5539/jas.v7n2p115.

Mucina, L., and M.C. Rutherford. 2011. The vegetation of South Africa, Lesotho and Swaziland, 513. Pretoria: SANBI.

Rasch, S., T. Heckelei, H. Storm, R. Oomen and C. Naumann. 2017. Multi-scale resilience of a communal rangeland system in South Africa. Ecological Economics, 131:129-138. http://dx.doi.org/10.1016/j.ecolecon.2016.08.012.

Scholtz, M.M., A. Maiwashe, F.W.C. Neser, A. Theunissen, W.J. Olivier, M.C. Mokolobate, and J. Hendriks. 2013. Livestock breeding for sustainability to mitigate global warming, with the emphasis on developing countries. South African Journal of Animal Science 43 (3): 269-281.

Scholtz, M.M. 2011. The Nguni and climatic challenges and opportunities. http://www.ngunicattle.info/Publications/Journals/2011/The\%20Nguni\%20 and\%20climate\%20change\%20-\%20Challenges\%20and\%20opportunities. pdf. Accessed 29 May 2015.

Spinka, M. 2006. How important is natural behaviour in animal farming systems Applied Animal Behaviour Science 100: 117-128 doi.org/10.1016/j.applanim. 2006.04.006.

Storm, I.M.L.D., A.L.F. Hellwing, N.I. Nielsen, and J. Madsen. 2012. Methods for measuring and estimating methane emission from ruminants. Animal 2: 160-183.

Tenney, S.M. 1982. Respiration in mammals. In Duke's physiology of domestic animals, 9th ed, ed. M.J. Swenson, 175-202. London: Cornell University Press Ltd.

Troy, S.M., C. Duthie, D.W. Ross, J.J. Hyslop, R. Roeche, A. Waterhouse, and J.A.A. Rooke. 2016. Comparison of methane emissions from beef cattle measured using methane hoods with those measured using respiration chambers. Animal Feed Science and Technology 211: 227-240.

van Oudtshoorn, F. 2012. Guide to grasses of southern Africa, 3rd edition, 45-257. Pretoria: Birza Publications.

Vendl, C., S. Frei, M.T. Dittmann, S. Furrer, S. Ortmann, A. Lawrenz, B. Lange, A. Munng, M. Kreuzer, and M. Clauss. 2016. Methane production by two nonruminant foregut-fermenting herbivores: The collared peccary (Pecari tajacu) and the pygmy hippopotamus (Hexaprotodon liberiensis). Comparative Biochemistry and Physiology Part A 191: 107-114. https://doi.org/10.1016/j. cbpa.2015.09.021.

\section{Submit your manuscript to a SpringerOpen ${ }^{\odot}$ journal and benefit from:}

- Convenient online submission

- Rigorous peer review

- Open access: articles freely available online

- High visibility within the field

- Retaining the copyright to your article

Submit your next manuscript at $\boldsymbol{\nabla}$ springeropen.com 